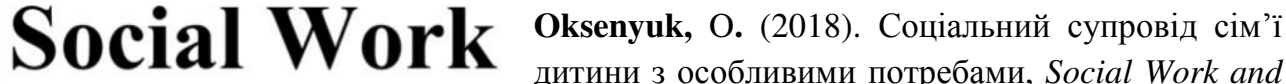 \& Education Education, vol. 5, No. 1. pp. 38-46.
}

C SW\&E, 2018

\author{
Oksana Oksenyuk, \\ PhD, Associate Professor, \\ Department of Pedagogy, \\ Educational Management and \\ Social Work, \\ Rivne State University of the \\ Humanities. \\ Rivne, Ukraine \\ oksana_oksenyuk@ukr.net
}

\section{Оксана Оксенюк,}

кандидат педагогічних наук, доиент,

кафедра педагогіки, освітнього менеджменту та соиіальної роботи,

Рівненський

державний

гуманітарний університет

м. Рівне, Україна

УДК 37. 018. 1-056

DOI: $10.25128 / 2520-6230.18 .1 .4$

Article history:

Received: Febuary 28, 2018

1st Revision: March 17, 2018

Accepted: March 27, 2018

\section{СОЦАЛЬНИЙ СУПРОВІД СІМ'Ї ДИТИНИ 3 ОСОБЛИВИМИ ПОТРЕБАМИ}

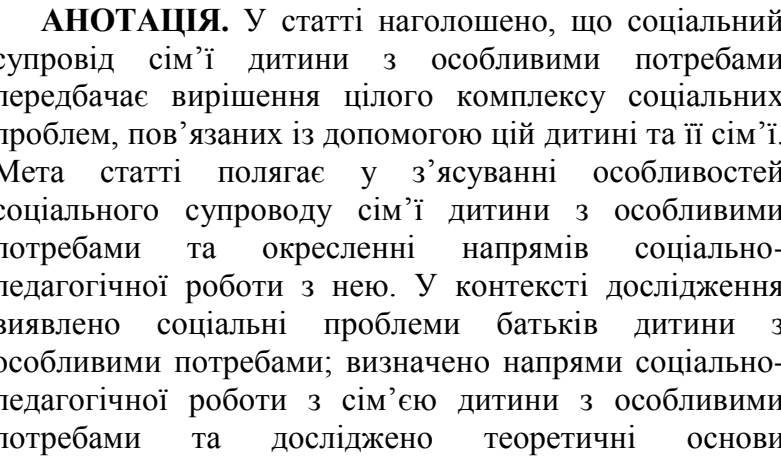
соціального супроводу означеної сім'ї. Констатовано, що підтримка соціального здоров'я сім'ї дитини 3 особливими потребами вимагає додаткових форм соціально-педагогічної діяльності (крім супроводу й консультування), спрямованих на допомогу батькам. Соціально-педагогічна допомога сім'ї, яка виховує дитину 3 особливими потребами $\epsilon$ завжди сімейно зорієнтованою і спрямованою на соціалізацію дитини. Основними принципами соціально-педагогічної роботи 3 такими родинами є єдність дій сім’ї і соціальних інститутів; активізація ролі батьків, їх навчання i включення у процес соціально-педагогічної діяльності.

Установлено, що в соціальному супроводі діяльність соціального працівника включає систематичну допомогу сім'ям, які виховують дитину 3 особливими потребами; створення центру психологомедико-педагогічної консультації таких сімей; організацію їх життедіяльності. Відповідно, зміст і складові дій соціального супроводу $€$ змістовоорганізаційною основою соціально-педагогічної роботи 3 сім'єю дитини з особливими потребами в цілому.

Ключові слова: дитина 3 особливими потребам; соціально-педагогічна робота; інклюзивна освіта; соціальний супровід. 


\section{Вступ}

Зростання народжуваності особливих дітей $є$ великою соціальною проблемою, яка набуває критичної ваги розхитування і так нестабільної соціальної ситуації в Україні. За даними Державної служби статистики України, на сьогоднішній день налічується приблизно 63,5 тис. дітей із особливими потребами. Зокрема, на Рівненщині проживає 6,5 тисяч дітей 3 особливими потребами, а це - десята частина від усієї держави (Діти з особливими потребами - особлива турбота, 2013). Соціальна дійсність та наукові розвідки звертають увагу на сім'ю особливої дитини як об'єкт соціальної роботи, бо сім'я залишається основним стабілізуючим чинником соціальної адаптації дитини.

Сучасна практика соціальної i корекційної педагогіки, спеціальної психології свідчить про необхідність активного вивчення всього спектра проблем сім’і, яка виховує дитину з особливостями психофізичного розвитку. Відповідно, акцент соціально-педагогічного впливу переноситься на сім'ю особливої дитини, де посилена увага приділяється позитивному впливу близьких на дитину із проблемами в розвитку, створенню сприятливих умов для іiі навчання не тільки в освітньому закладі, але і в домашніх умовах. Вивчення сім'ї з особливими дітьми як об'єкта соціально-педагогічної допомоги (І. Іванова, Р. Кравченко, М. Радченко, В. Тарасун); дослідження системних змін освіти для дітей 3 особливими потребами, що сприяють їх успішній інтеграції в суспільство (А. Колупаєва, О. Ляшенко), аспектів соціалізації дітей 3 інвалідністю (О. Безпалько, І. Звєрєва, А. Капська, Л. Міщик, В. Нікітіна) не вичерпують вирішення всього кола означеної проблеми дослідження.

Мета статті: 3’ясувати особливості соціального супроводу сім'“і дитини 3 особливими потребами та окреслити напрями соціально-педагогічної роботи 3 нею. Мету дослідження конкретизовано у завданнях: 1) виявити соціальні проблеми батьків дитини 3 особливими потребами; 2) визначити напрями соціально-педагогічної роботи 3 сім'єю дитини 3 особливими потребами; 3) дослідити теоретичні основи соціального супроводу сім’ї, що виховує дитину 3 особливими потребами.

Методологія дослідження - полідисциплінарна, що поєднує методологічні рівні та методологічні підходи, зокрема когнітивний, комплексний, особистісний тощо. Когнітивний і комплексний підходи дисциплінарного рівня методології, що базуються на загальнонаукових принципах, формах, підходах до відображення дійсності, дозволили застосувати наступні методи педагогічного дослідження: термінологічний аналіз - визначити використаний у дослідженні категорійнопонятійний апарат; метод узагальнення незалежних характеристик, порівняльний аналіз - з'ясувати поточний стан соціальних проблем сім'ї особливої дитини, а також напрями реалізації соціально-педагогічної роботи 3 сім'єю дитини 3 особливими потребами; систематизація, інтегрування, зіставлення - теоретично обгрунтувати організаційні основи здійснення соціального супроводу сім’і особливої дитини. Під час визначення досліджуваної проблеми застосовано теоретичні методи, пов'язані 3 вивченням наукової літератури, законодавчих документів, періодичних видань, електронних ресурсів загалом.

\section{Основна частина}


На відміну від міжнародної термінології, в Україні запропоновано використовувати для дітей із психофізичними порушеннями термін «діти 3 особливими потребами», який стосується різних нозологій та порушень різного ступеня ураження, таких як інвалідності у важкій формі, так і середнього ступеня тяжкості (Нагорна О. Б., 2016). Тоді як у світовій практиці до цієї групи прийнято зараховувати також дітей із незначними вадами здоров'я, соціальними проблемами та обдарованістю. Тобто «діти з особливими потребами»- поняття, яке охоплює всіх дітей, чиї освітні потреби виходять за межі загальноприйнятої норми. У вітчизняній практиці - це діти з порушеннями мовлення, із затримкою психічного розвитку, з вадами опорно-рухової системи, розладами емоційновольової сфери.

Проаналізуємо основні соціальні проблеми, 3 якими зіштовхуються у сьогоденні батьки особливої дитини (авт.: у намій статті поняття «особлива дитина» вжсто як синонімічне змісту понять «дитина з особливими потребами», «дитина з особливими освітніми потребами»).

Сім'ї, що мають дітей із порушеннями фізичного чи психічного розвитку, це одна $з$ найбільш уразливих груп населення. Труднощі, пов'язані з вихованням особливої дитини, зумовлюють якісні зміни в життедіяльності сім'ї, дезадаптують сім’ю та часто призводять до сімейної кризи. Узагальнений соціальнопсихологічний портрет батьків дітей $з$ особливими потребами характеризується вираженою стурбованістю, високим рівнем тривожності, слабкістю, соціальною боязливістю, підозрілістю. Із власної ініціативи батьки рідко контактують із незнайомими людьми, виявляють насторожене ставлення до всіх, хто намагається спілкуватися 3 дітьми. Жалість чи подив оточуючих, які побачили їх хвору дитину, призводить до того, що батьки починають приховувати дитину від сторонніх очей: вони намагаються не бувати з нею у громадських місцях, чим ще більше сприяють соціальній дезадаптації дитини. У цих сім'ях хвора дитина стає причиною сімейних конфліктів, що зумовлює дестабілізацію сімейних стосунків, часто - розпад сім'ї, а неповна сім'я - це гальмування фізичного і психічного розвитку особливої дитини. Дефект дитини деякі батьки сприймають як власну неповноцінність, як переживання провини перед дитиною та навколишнім оточенням (Буковська О. О., 2013; Ревть А. Б, 2015). Більшою мірою переживають почуття провини матері: у 70\% матерів особливих дітей наявне амбівалентне ставлення до дитини, суперечливість якого проявляється в тому, що дитина одночасно розглядається і як об'єкт любові, і як джерело страждань (що стає причиною частих нападів роздратування у відношенні до дитини). Однак, прийняття хворої дитини залежить не стільки від характеру захворювання дитини, скільки від психічних особливостей особистості матері та батька.

Установлено, що загальними соціальними проблемами сімей в Україні, які виховують дитину 3 особливими потребами, є наступні (Ревть А. Б, 2015; Царькова О. В, 2014): - порушення взаємодії з соціумом (рідні, знайомі, лікарі, педагоги, соціальні працівники та інші фахівці): замикання у своїй родині, неадекватна реакція на лікарські та педагогічні рекомендації, конфронтація 3 дитячими дошкільними чи шкільними закладами; - порушення внутрішніх сімейних відносин, особливо подружніх: батько часто знаходиться в ролі «занедбаного», а матір - «неповноцінної»; - порушення репродуктивної поведінки родини: у разі невеликого ризику народження дитини 3 тією ж патологією 
подружжя приймає рішення не мати більше дітей, і навпаки; - формування хибних поглядів, установок щодо лікування і виховання дитини: незворотність діагнозу та відповідні наслідки приймаються не відразу й не всіма членами сім’ї; - сприйняття проблеми як особистої та навмисне уникнення соціальної (державної, громадської) допомоги; - відсутність достовірної інформації про можливості корекції та лікування (у т.ч. безкоштовні медичні препарати), реабілітації, права на соціальну допомогу, пільги, відповідні заклади освіти, спеціалізовані державні і недержавні громадські організації; - незручне територіальне розташування спеціальних закладів освіти, труднощі адаптації в загальноосвітній школі через відсутність інклюзивних класів чи відповідної соціально-педагогічної роботи; низька матеріальна забезпеченість сімей, що виховують особливу дитину, труднощі в реалізації гарантованих пільг через неналежне виконання законів окремими ланками державного управління (як правило, вужчого - місцевого масштабу); - неприйняття людей із особливими потребами повноцінними членами суспільства, упередженість і стереотипність у ставленні до них, а також до їхніх сімей; - відсутній чи обмежений доступ до певних об'єктів, споруд, проблеми транспортного забезпечення тощо.

Звідси, соціальна підтримка таких сімей - це вирішення цілого комплексу соціальних проблем, пов'язаних із допомогою особливій дитині та іiі сім'ї: 3 їі виживанням, лікуванням, реабілітацією, освітою, соціальною адаптацією та інтеграцією у суспільство (інформаційною, культурною, трудовою i т.д.). Підтримка соціального здоров'я родини особливої дитини вимагає додаткових форм соціально-педагогічної діяльності (крім супроводу й консультування), спрямованих на допомогу батькам. Це соціальна реабілітація і соціальна інтеграція родини, тобто відновлення ії соціального статусу.

Отже, соціально-педагогічна допомога сім’і, яка виховує дитину 3 особливими потребами, - це завжди сімейно зорієнтована практика, що спрямована на соціалізацію дитини. Відповідно, основними принципами соціально-педагогічної роботи з такими родинами є єдність дій сім’ї і соціальних інститутів; активізація ролі батьків, їх навчання і включення у процес соціальнопедагогічної діяльності.

У грудні 2009 року Україна ратифікувала Конвенцію про права інвалідів, у 2010 році наказом Міністерства освіти і науки України затверджено Концепцію розвитку інклюзивної освіти. Мета Концепції - створення умов для вдосконалення системи освіти й соціальної реабілітації дітей 3 особливими освітніми потребами, у тому числі 3 інвалідністю, шляхом упровадження інклюзивного навчання; формування нової філософії суспільства щодо позитивного ставлення до дітей та осіб з порушеннями психофізичного розвитку та інвалідністю. Відповідно до мети основними завданнями реалізації Концепції визнано формування освітньо-розвивального середовища для дітей з особливими освітніми потребами через забезпечення психолого-педагогічного, медикосоціального супроводу; впровадження інклюзивної моделі навчання у загальноосвітніх навчальних закладах 3 урахуванням потреб суспільства (Концепція розвитку інклюзивної освіти, 2010).

Відповідно, розширюються завдання, обов'язки й можливості діяльності соціальних працівників в освітніх закладах. 
Найважливішим досягненням минулого року в поширенні інклюзивної освіти визнано те, що 12.05.2017 року Верховна Рада України прийняла, а 05.07.2017 року Президент підписав законопроект № 6437 «Про внесення змін до закону України «Про освіту» щодо особливостей доступу осіб з особливими освітніми потребами до освітніх послуг» (Закон України «Про внесення змін...», 2017), ініціатором якого стала дружина чинного президента Марина Порошенко. Законопроект закріпив права на освіту осіб з особливими потребами і надав їм можливість отримувати освіту в усіх навчальних закладах, у тому числі безоплатно в державних i комунальних навчальних закладах, ураховуючи дистанційну й індивідуальну форми навчання. Крім того, закон регулює реалізацію можливості надання особам з особливими потребами психологопедагогічної та корекційно-розвивальної допомоги, створення інклюзивних та спеціальних груп (класів) у загальноосвітніх навчальних закладах. Послідовно набули чинності постанови Кабінету Міністрів України «Про затвердження Положення про інклюзивно-ресурсний центр» (12.07.2017р.) (Про затвердження Положення про..., 2017), «Про внесення змін до Порядку організації інклюзивного навчання у загальноосвітніх навчальних закладах» $(9.08 .2017$ р.) (Про внесення змін до Порядку..., 2017).

Нещодавно Рівненщина долучилася до Всеукраїнського проекту Благодійного Фонду П. Порошенка щодо розвитку інклюзивної освіти. Відповідний Меморандум про співпрацю підписали М. Порошенко та голова Рівненської ОДА О. Муляренко. У рамках співпраці 09.11.2017 року Рівненську ЗОШ № 24 (м. Рівне) відвідала М. Порошенко, де ознайомилася із досвідом діючих інклюзивних класів. Загалом, на Рівненщині інклюзивне навчання організовано у 158 школах, що на 62 більше, ніж у попередньому навчальному році. Функціонує 282 інклюзивні класи, в яких навчається 358 дітей з особливими потребами. Для супроводу дітей уведено 217 посад асистента вчителя (На Рівненщині готують фахівців з особливої освіти, 2017).

Загалом, можна констатувати, що інклюзивна освіта в Україні сьогодні проходить етап активної адаптації й організаційно-методичної корекції в загальноосвітніх закладах. У стадії розробки перебуває облікування рамок і нормативів діяльності фахівців соціальної роботи в загальноосвітніх закладах для роботи 3 дітьми з особливими потребами і їхніми сім'ями. А власне соціальнопедагогічна робота 3 дітьми 3 особливими потребами в освітній сфері $\epsilon$ інваріантом реалізації інклюзивного навчання.

У Державному стандарті соціального супроводу сімей (осіб), які перебувають у складних життєвих обставинах (поточна редакція від 10.03.2017 р.) зазначено, що соціальна послуга соціального супроводу передбачає відвідування отримувача послуги за місцем його проживання; оцінку потреб сім’ї й особи отримувача; складання індивідуального плану супроводу і його корекцію; інформування отримувача про надання пакета соціальних послуг та соціальної допомоги; проведення бесід, психологічну підтримку й організацію сімейних нарад, мережевих зустрічей, тренінгів; допомогу в отриманні спеціалізованих послуг; забезпечення діяльності груп взаємодопомоги і ведення документації (Про затвердження Державного стандарту соціального супроводу сімей (осіб), які перебувають у складних життєвих обставинах, 2017). 
Тобто зміст і складові дій соціального супроводу є змістово-організаційною основою соціально-педагогічної роботи з сім'єю особливої дитини в цілому.

$\mathrm{У}$ комплексній програмі інклюзивного навчання співпраця 3 батьками $€$ чинником забезпечення корекційного впливу на дитину та досягнення іii оптимального розвитку. Батьки стають активними учасниками реабілітаційного процесу, спрямованого на компенсацію рухових розладів, забезпечуючи безперервність розвивального впливу на дитину 3 особливими потребами. Формами взаємодії з батьками у соціальному супроводі будуть: індивідуальна, колективна, наочна, індивідуальні бесіди і практикуми, консультування, семінари, лекції, соціологічні дослідження, взаємодія 3 громадськими організаціями (Нагорна О. Б., 2016).

У соціальному супроводі діяльність соціального працівника буде включати систематичну допомогу сім'ям, які виховують дитину з особливими потребами; створення центру психолого-медико-педагогічної консультації таких сімей; організацію життєдіяльності сімей, які виховують дитину 3 особливими потребами. Етапами здійснення соціального супроводу будуть: niдготовчий (встановлення контакту з усіма учасниками супроводу дитини; визначення обсягу роботи і послідовності процесу супроводу; підготовка необхідної документації; складання графіка роботи); орієнтовний (встановлення контакту з батьками і родичами дитини; встановленні контакту з групою, яку відвідує дитина; якщо супровід дитини здійснюється у межах школи або дитячого садка, то з класним керівником або вихователем; ознайомлення фахівців з результатами соціальнопедагогічного, соціально-психологічного обстеження; спільне обговорення 3 педагогами та іншими фахівцями особливостей розвитку дитини); планувальний (створення індивідуальної програми супроводу сім’ї; затвердження цієї програми фахівцями, які працюють із сім'єю; впровадження програми супроводу); заключний (обговорення 3 фахівцями ефективності здійснення роботи 3 рекомендаціями щодо подальшої діяльності сім'ї) (Діти з особливими потребами - особлива турбота, 2013).

Отже, соціальний супровід - це один із видів соціального патронажу як комплексної системи соціальної підтримки і допомоги, що здійснюється у межах діяльності соціальних служб; це інтегративна технологія, сутність якої полягає у створенні умов для відновлення потенціалу розвитку сім'ї й особливої дитини; це процес особливого виду соціальних відносин між тим, хто супроводжує, і тим, хто потребує допомоги.

\section{Висновки}

У кінцевому результаті можемо стверджувати, що сучасне реформування надання соціальних послуг населенню, зокрема - соціального супроводу сім'ям чи особам, які перебувають у складних життєвих обставинах, має нагальне значення (економічна нестабільність, проблема біженців і переселенців через війну на Сході України, міграція населення трудового віку за кордон) і практичну зумовленість. Та попри чітке розкриття змісту й порядковості проведення дій соціального супроводу, зазначено, що він обмежений часом і кількістю випадків застосування, тоді як сім'я особливої дитини потребує цього супроводу значно довше і частіше, адже діти з віком стають дорослими, по відношенню до яких соціальний супровід має змінювати лише форму вияву, але не зміст. 


\section{Література}

Буковська, О. О. (2013). Напрямки психологічної допомоги сім'ям, які виховують дитину з особливими потребами. Вісник Чернігівського національного педагогічного університету. Сер.: Психологічні науки. (114), 12-16. [Електронний pecypc]. Режим достуny: http://nbuv.gov.ua/UJRN/VchdpuPH_2013_114_5.

Концепція розвитку інклюзивної освіти. (2010). Дефектолог. (3(39), 3-5.

Закон України «Про внесення змін до закону України «Про освіту» щодо особливостей доступу осіб з особливими освітніми потребами до освітніх послуг». (08.07.2017). [Електронний ресурс]. Режим достуnу: ukrainepravo.com/.../iansrtsnualry-tus-vryefyerrya-ipkr-es-i...

Про затвердження Положення про інклюзивно-ресурсний центр. (12.07.2017). [Електронний ресурс]. Режсим доступу: zakon.rada.gov.ua/go/545-2017-п... .

Про внесення змін до Порядку організації інклюзивного навчання у загальноосвітніх навчальних закладах. (09.08.2017). [Електронний ресурс]. Режим досmyny: zakon.rada.gov.ua/go/588-2017-п.... .

Нагорна, О. Б. (2016). Особливості корекційно-виховної роботи 3 дітьми 3 особливими освітніми потребами. Рівне, НУВГП.

Ревть, А. Б. (2015). Інноваційний досвід соціально-реабілітаційної роботи 3 дітьми-інвалідами та їх батьками в Україні. Людинознавчі студії. Педагогіка. (1(33), 169-175. [Електронний ресурс]. Режим доступу: http://nbuv.gov.ua/UJRN/Lstud_2015_1(33)_22.

Царькова, О. В. (2014). Особливості допомоги батькам, які виховують дітей 3 особливими потребами. Проблеми сучасної психологї̈. (23), 687-697. [Електронний pесурс]. Режим доступу: http://nbuv.gov.ua/UJRN/Pspl_2014_23_62.

Якою буде інклюзивна освіта на Рівненщині. (18.05.2017). Маленькі рівняни. ОГО. [Електронний ресурс]. Режсим достуnу: http://dity.ogo.ua/hotnews/yakoyu-budeinklyuzivna-osvita-na-rivnenshhini/.

Діти з особливими потребами - особлива турбота. (29.04.2013). Рівненська обласна державна адміністраиія. [Електронний ресурс]. Режим доступу: http://www.rv.gov.ua/sitenew/main/ua/publication/ content/20257.htm

На Рівненщині готують фахівців 3 особливої освіти. (16.11.2017). [Електронний pecypc]. Режим доступy: http://mon.gov.ua/usi-novini/novinioblastej/2017/11/16/na-rivnenshhini-gotuyut-faxivcziv-z-osoblivoyi-osviti/.

Про затвердження Державного стандарту соціального супроводу сімей (осіб), які перебувають у складних життєвих обставинах. (10.03.2017). Верховна Рада України. [Електронний ресурс]. Режсим доступу: http://zakon.rada.gov.ua/laws/show/z0621-16. 


\title{
SOCIAL ACCOMPANIMENT OF THE FAMILY WHO HAS A CHILD WITH SPECIAL NEEDS
}

\author{
Oksana Oksenyuk, PhD, Associate Professor, \\ Department of Pedagogy, Educational Management and Social Work, \\ Rivne State University of the Humanities, Rivne, Ukraine, \\ oksana_oksenyuk@ukr.net
}

\begin{abstract}
The article emphasizes that social support for the family who has a child with special needs is the solution to a whole range of social problems associated with helping the child and his family: with its survival, treatment, rehabilitation, education, social adaptation and integration into society. The purpose of the article is to find out the features of social accompaniment of a child with the special needs and to define the social and pedagogical work assignments. The tasks of the article is to exposure of social problems of parents who have a child with special needs; to determin of social and pedagogical work with family, who has a child with special needs; to research theoretical bases of social accompaniment of family, which educates a child with special needs. The methodology of research is polidisciplinarny; it combines cognitive complex and personal approaches.

It is stated that support for the social health of the family who has a child with special needs requires additional forms of social-pedagogical activity (except of accompaniment and counsultansy) aimed at helping parents. Social and pedagogical help of family, which educates a child with the special needs, is always family orientated practice, which is directed on child socialization. In accordance, the basic principles of social and pedagogical work with such families is unity of family activities and social institutes; activation parents'of role, their training and engagement in to social and pedagogical activities. Inclusive education in Ukraine (including Rivne region) is at the stage of active adaptation, organizational and methodological correction in general educational institutions now. The accounting of the framework and standards for the activities of social work of specialists in general educational institutions for the work with the children who have special needs and their families are at the stage of development. And actually social and pedagogical work with children who have special needs in the educational sphere is an invariant of the implementation of inclusive education.

It's defined that social accompaniment of the social worker's activity will include a systematic help to families, which educate a child with special needs; creation of the center of psychological, medical and pedagogical consultation of such families; organization of their activities. It is established that the content and the components of social support are the content and organizational basis of the social and pedagogical work with the family of a child with special needs in general.
\end{abstract}

Key words: child with special needs; social and pedagogical work; inclusive education; social support.

\section{References}


Bukowski, E. (2013). Directions of psychological assistance to families raising a child with special needs. Bulletin of Chernihiv national pedagogical University. Ser.: Psychological science. (114), 12-16. Retrieved from: http://nbuv.gov.ua/ UJRN/VchdpuPH_2013_114_5. [in Ukrainian].

The concept of development of inclusive education. (2010). The defectologist. (3 (39), 3-5. [in Ukrainian].

Law of Ukraine «On making alteration in the law of Ukraine «On education» in relation to the features of access of people with the special educational needs to educational services». (08.07.2017). Retrieved from: ukrainepravo.com/.../iansr-tsnualrytus-vryefyerrya-ipkr-es-i... [in Ukrainian].

About claim of Statute about a inclusive and resources center. (12.07.2017). Retrieved from: zakon.rada.gov.ua/go/545-2017-п... . [in Ukrainian].

About making alteration to Order of organization of inclusive studies in general educational establishments. (09.08.2017). Retrieved from: zakon.rada.gov.ua/go/5882017-п... . [in Ukrainian].

Nagorna, O. (2016). Features of correctional and educational work with children with special educational needs: educational and methodical method. Rivne, NUWE. [in Ukrainian].

Revt, A. (2015). Innovative experience of social and rehabilitation work with children with disabilities and their parents in Ukraine. Liudynoznavchi studii. Pedagogy. (1(33), 169-175. Retrieved from: http://nbuv.gov.ua/UJRN/Lstud_2015_1(33)_22. [in Ukrainian].

Tsar'kova, A. (2014). Features of help to parents, who are raising children with special needs. Problems of modern psychology. (23), 687-697. Retrieved from: http://nbuv.gov.ua/UJRN/Pspl_2014_23_62. [in Ukrainian].

What will be inclusive education in the region. (2017). Malen'ki rivniany. Retrieved from: http://dity.ogo.ua/hotnews/yakoyu-bude-inklyuzivna-osvita-na-rivnenshhini/. [in Ukrainian].

Children with special needs - a special care. (2013). The Rivne regional state administration. Retrieved from: http://www.rv.gov.ua/sitenew/ main/ua/publication/ content/20257.htm. [in Ukrainian].

Training of specialists to special education in the Rivne region. (2017). The Ministry of education and science of Ukraine. Retrieved from: http://mon.gov.ua/ all news areas/2017/11/16. [in Ukrainian].

About approval of State standard of social support to families (persons), who are in difficult life conditions. (2017). The Verkhovna Rada of Ukraine. Retrieved from: http://zakon.rada.gov.ua/laws/show/z0621-16. [in Ukrainian]. 
